\title{
CHINESE EDUCATION IN THE NOVEL BATTLE HYMN OF THE TIGER MOTHER BY AMY CHUA
}

\author{
MAGDA WIETESKA \\ Faculty of Pedagogy, University of Wrocław \\ ul. J.Wł. Dawida 1, 50-527 Wrocław, Poland \\ E-mail address: mag.wieteska@gmail.com
}

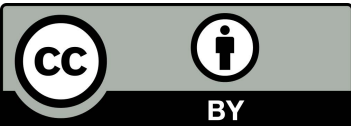

\begin{abstract}
Chinese culture and tradition stand in direct opposition to American and European cultures. Chinese children must live according to the principles of metaconfucianism from an early age. Failure to do so threatens social ostracism.

Amy Chua in her autobiographical novel Battle Hymn of the Tiger Mother describes the education of her two daughters living in America according to the principles present in China. The educational methods used by Chua are considered controversial by western parents. The author made an attempt to explain the motives of Asian mothers.

Key words: education, China, metaconfucianism, culture, tradition, ren
\end{abstract}

"America changes people. When I was four, my father said to me,

"You will marry a non-Chinese over my dead body«" (Chua, 2011, pp.

26-27)

Every culture in the world has different norms, values, beliefs. It is multifaceted, dynamic and variable, but at the same time ordered, understandable, processed, although discontinuous (Burszta, 1998). You can compare it to a coral reef - "a powerful, old accumulation of organic waste, big, significant structure which can act by itself" (Kroeber, 2007, p. 287). An organism such as that can function similarly to a group of living polyps from which a single one is hardly individual, but its activity and influence are clearly visible (Kroeber, 2007 ).

Forms of ritualization, that is patterns of lifestyle and customs, are created by every culture (Gajda, 2003). They set a certain standard for personality which differs depending on a society. The influence that culture has on a human being originates from a culturally modelled behaviour of other individuals in relation with their children. This behaviour gains its fundamental meaning in early childhood (Linton, 2007). Interestingly, these patterns do not necessarily have a direct impact on the child, but through observation they can become role models to follow in the child's adult life. It is a common 
occurrence that parents raise their children based on their own, culturally conditioned upbringing. This is the case with Amy Chua, the author of the novel Battle hymn of the tiger mother. Born in the USA as a daughter of Chinese immigrants and later a mother to two girls, this is how she recalls her own childhood:

"Growing up in the Midwest, my three younger sisters and I always knew that we were different from everyone else. Mortifyingly, we brought Chinese food in thermoses to school (...) We were required to speak Chinese at home (...) Every evening when my father came home from work, I took off his shoes and socks and brought him his slippers." (Chua, 2011, p. 25)

The girls did their homework and had piano lessons in the afternoons and were never allowed to stay overnight at their friend's house. The parents demanded that their children received only the highest grades.

We could easily consider such a childhood as a nightmare. Chua, however, denies this view, claiming that the family actually provided her strength and confidence.

The author is a professor of law at Yale University. She has worked in editorial offices of prestigious academic journals, which was where she met her future husband. Contrary to the expectations of her parents, she did not marry a Chinese man, but despite that, with admirable determination, she adopted the Chinese model of education as the method of upbringing for her daughters.

This form of education consists of several main rules and does not differ much from the one Chua experienced herself.

The list of things forbidden for children to do is not long at all, in addition it is written in a humorous way. Here are the main commandments. Children are not allowed to play, to stay overnight at their friends' house, attend in school theatre plays (note - it is also not allowed to complain about not participating in these plays!). It is forbidden to watch television and play computer games. Children must not decide about their interests or receive grades lower than $\mathrm{A}$. You need to be a top student and to play the piano or violin. Chua emphasizes that "classical music was the opposite of decline, the opposite of laziness, vulgarity, and spoiledness. But it was also a tie-in to the high cultural tradition of my ancient ancestors" (Chua, 2011, p. 30). She also argues that "Chinese parents demand perfect grades because they believe that their child can get them" (Chua, 2011, p. 59). She shows the contrast between a western parent who praises the child for getting an A-minus, while a Chinese parent scolds them (Chua, 2011, p. 67).

For western parents mere reading of these principles may seem like a shocking abstraction. However, in order to prevent rash conclusions we need to take a closer look at the origins of Chinese education. 


\section{METACONFUCIANISM OF AN ORDINARY MAN}

Chinese culture and tradition stand in complete opposition to American and European cultures.

"China is the oldest civilization to survive in the modern world, a culture that has been forming for centuries. Many of its traditional values have remained to this day it is not surprising that the Chinese possess their own norms which they deem most appropriate and generally applicable" (Wicher, 2012, p. 92).

Wojcik also mentions that the ideals or views in the Western philosophy are almost completely absent in the Chinese philosophy (2012, p. 57).

Bauer, a German sinologist, puts the Chinese and Western European cultures on opposing sides while analysing them (After: Weggel, 2006, p. 30). Chinese culture is centrist, while Western European culture is extremist. Gentle and moderate Chinese education is rival to the social conflict and strength associated with Western European societies. In Chinese ethics an emphasis is put on family, contrary to the focus on an individual present in Western Europe. The Chinese love everything that is old, Europeans love novelties. Chinese are characterized by sublimation, integrity and respect for education. Western Europe focuses on values such as respect for wisdom, strength, the law and profit.

Weggel mentions the confrontation of a Chinese child's life with the social principles present in his country of origin which occurs already in the early years of its life. Acceptance of specific social roles is essential in order to function properly because failure to do so may result in a certain form of ostracism: rejection by the society and hostility (Weggel, 2006, p. 31) This is metaconfucianism, a "confucianism of a small tradition (...) of an average human (...) [which] is a basis for a typical Chinese person to assess what is "normal «" (Weggel, 2006, p. 31) In metaconfucianism, emphasis is put on "we" instead of " $I$ ", the duties stand before the laws. Interdependence displaces personal gain. There is a desire for consensus rather than conflict. A sense of shame here replaces guilt, social ties win against the laissez-faire. Conformism triumphs over individualism, and the chief slogan is: "Remove yourself to benefit the whole" (Weggel, p. 33). Ren, or the virtue of humanity, marks China's moral foundation, created by the community bonds (Wesołowski, 2006). Because what truly makes a person a human being is acting "first within the family, tribe or clan, as they are the oldest and most basic form of interpersonal relationship, relationship of blood" (Wesołowski, 2006).

\section{CULTURAL CONDITIONING OF CHINESE EDUCATION}

In order to understand the motives of Asian parents, we firstly need to understand the mechanism of Chinese education. It assumes that after being born, a child automatically joins a particular social group. This group together 
with its culture creates an understandable world for a newborn and determines its patterns and norms of behaviour which are supervised by the adult members of the community (Petrykowski, 2005). It is worth adding that in addition to Confucianism two other systems of philosophy and religion, Taoism and Buddhism, have an impact on Chinese perception of the world and education of Chinese children.

According to the Chinese education, it is the children that are indebted to their parents. A. Chua mentions the Confucian humility as a basis of Chinese culture. According to the teachings of Confucius, a traditional family relies on the hierarchy of its members. The children are subordinate to their parents and their duty is to listen to them, to bring them pride and glory and to tend to them when they grow old. "In Chinese culture, it just wouldn't occur to children to question, disobey, or talk back to their parents" (Chua, 2011, p. 32).

A Chinese daily newspaper from Wuzhou, a city in the province of Guanxi, suggests specific solutions in this regard, including regular medical check-ups of parents or making sure that they always have some small amount of money to spend. It advises the readers to bring the parents on meetings with friends, to make photographs of the parents, have frequent and long conversations with them, carefully reply to their text messages, organizing their birthday parties, buying insurance, as well as show love and do sports together (Kruczkowska, 2015). A. Chua mentions her mother-in-law's illness and the author's decision to take her to her home to take care of her mother-in-law. "Your parents are your parents, you owe everything to them (even if you don't), and you have to do everything for them (even if it destroys your life)" (Chua, 2011, p. 100). The difference between Chinese and Western upbringing shows the reaction of her husband, who, despite love for her mother, did not come to mind. What is more - he did not feel like living with his mother.

In comparison to the aforementioned duties adult Europeans and Americans seem to downright neglect their parents. After all, there is no tradition of materially supporting aging mothers and fathers in our culture. Quite the contrary - it is often the parents that financially support their adult daughters and sons. Joint physical activities are also something that is beyond the European understanding of caring for aging parents. Again, these differences are caused by cultural disparity - it is enough to mention that the majority of Chinese, regardless of age, regularly engage in physical activity. In Europe and the United States of America this trend usually applies to people in early and middle adulthood.

Then what do Chinese parents do in regard to their children? They help them to uphold tradition. They drill them, but for a good cause. Moreover, they assume that every child is able to learn complex skills and that only few are gifted with talent, but with work, perseverance and consistency you can achieve success just the same. "(...) The Chinese believe that the best way to protect their children is by preparing them for the future, letting them see what they're capable of, and arming them with skills, work habits, and inner confidence that no one can ever take away" (Chua, 2011, p. 69). 
In Chinese culture there is no room for opposition, conflict of generations or objectification of children: "Finally, I tried to demand as much respect from the girls as my parents did of me. (...) Growing up, I was terrified of my parents' disapproval" (Chua, 2011, p. 34).

However, no one speaks against it. Why? Because Chinese parents give their children strength and unwavering confidence, as mentioned by Chua. Western parents believe instead that coercion violates the sovereignty of the child, weakens its self-esteem, and finally - that the children compelled to do anything in childhood will be unhappy in the future. "Western parents try to respect their children's individuality, encouraging them to pursue their true passions, supporting their choices, and providing positive reinforcement and a nurturing environment" (Chua, 2011, p. 69). But A. Chua thinks that it is the Chinese parents that are more concerned about their children: "On the flip side, there's nothing better for building confidence than learning you can do something you thought you couldn't" (2011, p. 69).

When speaking of Western education modeled on Western culture, it is hard not to mention the role of pluralism in the postmodern world. Nowadays everyone is on their own and the institutions of collective life ceased to be responsible for a decent life of an individual. Lifestyle choice is not dictated by anyone, so we can do whatever we want, but the consequence of it is a purely personal responsibility for our actions and choices. There are no links in the form of authorities, especially moral ones. Tradition becomes gradually less relevant. Relationships between people are less often based on feelings, emotional bond fades, so-called "pure relationships" (Giddens, 2006) that rely on satisfying only one need, are formed and quickly disbanded when this need disappears or is replaced by another, more urgent one.

The individualized Western society therefore has no singular cultural source, as opposed to Eastern societies based on centuries-old traditions, moral and legal norms as well as a sense of separation.

\section{THE WEST VERSUS THE EAST}

The Chinese are an example of a society in which "the cultural model requires absolute obedience of a child to its parents as the initial condition of receiving any rewards" (Linton, 2007, p. 467). As emphasized by A. Chua: "Chinese parents believe that they know what is best for their children and therefore override all of their children's own desires and preferences" (2011, p. 60).

The rewards themselves are given only when they are earned, that is when a child achieves a spectacular success. Compliments serve only to increase the child's self-esteem, although they are given only at home, never in public. The writer tells the story of her birthday. from her younger daughter she received a card which took no more than 20 seconds to make. Therefore Chua gave her daughter the card back, saying that she did not want it. "I want a better one one that you've put some thought and effort into" (2011, p. 105). Likewise, she 
rejected the card from the older daughter. She explained to the children that at their age she wrote poems for her mother's birthday, cleaned up the whole house and made breakfast. As a result, the girls once again wrote the cards, which this time were deemed satisfactory by their mother.

Interestingly, the experience of A. Chua clearly shows that such a model of Chinese education does not impair a child's self-esteem. Quite the contrary - it brings out confidence and ambition. Naturally, we cannot generalize this case and take into consideration the fact that both daughters of the author were exceptionally skillful from a young age (older sister Sophia learned the alphabet at one and a half years old, younger sister Lulu had an exceptional sense of hearing in music). On the other hand, the youngest sister of Chua had Down's Syndrome, but achieved great success in International Special Olympics. This last example perfectly shows the grounds for the validity of Chinese education: you do not have to be born a genius to achieve success.

Daily musical instrument playing lessons lasting many hours, orders and prohibitions are only one side of the form of education described and advocated by the author of Battle hymn of the tiger mother. An observant reader will notice the deep emotional contact between the mother and her daughters, her almost boundless commitment to their education, supported by persistence, consistence and great faith in her daughters' capabilities.

Chua is a controversial figure, but only in the reception of Western readers used to the concept of a non-stressful education rather than one based on autocracy. For could a Western parent imagine that their child had no choice of its own interests? But on the other hand, could that parent also imagine spending his or her whole free time on educating the child?

For Chinese parents such as Chua this is not difficult as a task. Even though she had no musical education herself, she learns on her own in order to understand the basics of playing a piano and violin, and also in order to be able to provide her daughters help at home after the lessons. Although the method of helping was quite controversial. The older daughter of the author recalls what she heard most often from her mother during the practice: "If the next time's not PERFECT, I'm going to TAKE ALL YOUR STUFFED ANIMALS AND BURN THEM!" (Chua, 2011, p. 35). But this is only one side of the story. The other is the reaction of the daughters. Chua stresses that the methods have brought the desired result. The mother had faith and a goal and the daughter was able to talk sense into her mother whenever she lost control over herself and hurt Sophie.

The writer does not lack self-critique, she regrets some of her reactions and words that she let out, but it does not change the fact that she considers her Chinese education as the best way for her children to achieve happiness. "I'm pretty sure (...) that everything I do is unequivocally $100 \%$ for my daughters. My main evidence is that so much of what I do with Sophia and Lulu is miserable, exhausting, and not remotely fun for me." (Chua, 2011, p. 147).

And the mistakes that she made? That she yelled at her daughters, insulted them at times? She is only a human after all, and even though Chua is a strong 
Chinese woman, she is not made of iron or steel. In admitting to her mistakes and most importantly, in admitting to the existence of facts that do not speak well about her, she is simply a human being. She could have kept some events private, but she refused to do so. For example, Chua called her daughter "garbage" when she expressed a blatant lack of respect to her mother. Surprisingly, she talks about it publicly when he meets friends (Chua, 2011, p. 66).

For her honesty Chua received a certain punishment - after publishing her book there were many voices of criticism and even a call for lynching. Worth noting is the fact that the daughters of Chua stood in defense of their mother, despite being so abused in the view of Western readers (Chua has also discussed the content of the novel with the daughters). In China on the other hand Battle hymn of the tiger mother was interpreted very differently - as promoting freedom in the education of children.

It is hard to say whether Western or Polish parents could afford to make such a sacrifice, which at the same time they would consider more of a tyranny. After all, Chua, as a daughter of Chinese immigrants and married to a man raised in an entirely culturally different society, had much more difficult conditions for raising her children in a Confucian spirit than Chinese mothers living in the country of birth of this great philosopher. Not without interest is also the fact that the United States is a country with a very casual approach to tradition and customs. A country where children are raised in such a way as to expose them to the least amount of stress which revolves around constantly enforcing their self-esteem by commending them without a reason and protecting them from nearly the whole world. And these values are entirely contrary to the Chinese education. As stated by Chua herself upon comparing both models: "Western parents are concerned about their children's psyches. Chinese parents are not. They assume strength, not fragility, and as a result they behave very differently." (Chua, 2011, p. 59).

\section{CONCLUSIONS}

The differences between educational methods in Europe and the United States of America and educating in the spirit of Confucianism is so significant that it is difficult to find any similarities between the two methods. The origins of the upbringing of Chinese children have their roots in the philosophical system and culture of this country. "In the whole world there is no society more oriented toward education that metaconfucian societies, [which] are based on the idea that a human can not only be brought up, but also achieve perfection" (Weggel, 2006, p. 46). By internalizing Confucian values, the author of Battle hymn of the tiger mother proves that the aforementioned words can be made reality. The author openly states that even though the United States provided her many privileges, the detachment from her cultural roots was a painful experience. "A tiny part of me regrets that I didn't marry another Chinese person and worries that I am letting down four thousand years of civilization. But most of me feels tremendous grati- 
tude for the freedom and creative opportunity that America has given me" (Chua, 2011, p. 27).

The feeling of being an outsider did not however affect Chua's approach to the education of children, but rather strengthened her belief in the continuation of the cultural traditions of her ancestors and faith in the importance of an ancient relationship with family and tribesmen (Hann, 2000, p. 240). We can state that Chua has embraced the primary identity, which is the one that produces the strongest and therefore the longest lasting forms of belonging.

\section{REFERENCES}

[1] Burszta, W. J. (1998). Antropologia kultury. Tematy, teorie, interpretacje [Anthropology of culture. Topics, theories, interpretations]. Poznań: Zyski S-ka.

[2] Chua, A. (2011). Battle hymn of the tiger mother. New York.

[3] Gajda, J. (2003). Antropologia kulturowa, cz.1. [Cultural antropology, part 1].Toruń: Impuls.

[4] Giddens, A. (2006). Przemiany intymności. Seksualność, miłość i erotyzm we współczesnych społeczeństwach [The Transformation of Intimacy: Sexuality, Love and Eroticism in Modern Societies]. Warszawa: PWN.

[5] Gołaszewska, M. (2003). Sposób istnienia wartości [A mean of the existence of value]. In: J. Gajda (Eds.). Antropologia kulturowa, cz.1. Wprowadzenie do wiedzy o kulturze [Cultural Antropology, part 1. Introduction to knowledge of culture]. Torun: Impuls.

[6] Hann, C. (2000). Antropologia społeczna [Social Anthropology]. Kraków: Wydawnictwo Uniwersytetu Jagiellońskiego.

[7] Kroeber ,A. L. (2007). Istota kultury [The essence of culture]. In: E. Nowicka E., M. Głowacka-Grajper (Eds.) Świat człowieka - świat kultury. Antologia tekstów klasycznej antropologii [The world of a human - the world of culture. The anthology of texts of classic antropology]. Warszawa: PWN.

[8] Kruczkowska, M. (2015). Chiński styl życia. Bunt? A co to takiego? [Chinese lifestyle. Rebellion? What is that?]. Retrieved March 1st, 2017 from http:/ / www.wysokieobcasy.pl/wysokieobcasy/1,80530,12886279,Chinski_styl_zycia_Bunt_A_co_to_takiego_html.

[9] Linton, R. (2007). Rola kultury w kształtowaniu osobowości [The role of culture in the forming of personality]. In: E. Nowicka E., M. Głowacka-Grajper (Eds.) Świat człowieka - świat kultury. Antologia tekstów klasycznej antropologii [The world of a human - the world of culture. The anthology of texts of classic antropology]. Warszawa: PWN.

[10] Petrykowski, P. (2005). Społeczno - kulturowe aspekty podstaw wychowania [Sociocultural aspects of the fundamentals of education]. Torun: Wydawnictwo Uczelniane WSIiE TWP.

[11] Weggel, O. (2006). Chiny [China]. Warszawa: Cyklady.

[12] Wesołowski, Z. (2011). Zrozumieć Chińczyków. Kulturowe kody społeczności chińskich [To understand the Chinese. Cultural codes of Chinese societies]. Warszawa: Wydawnictwo Akademickie Dialog.

[13] Wicher, J. (2012). Komunikacja z perspektywy różnych kultur na przykładzie kręgu kultury europejskiej i chińskiej, czyli czy obcy może stać się swój? [Communication in the view of different cultures on the example of European and Chinese culture, or can an outsider become ours? ]. In: H. Grzesiak, M. Fryza, K. Ratajczak (Eds.). Wykluczenie społeczne wczoraj i dziś [Social ostracism yesterday and today]. Poznań: Uniwersytet im. Adama Mickiewicza.

[14] Wójcik, A. I. (2012). Metodologia kręgów kulturowych Wschodu i Zachodu [Methodology of the cultural spheres of the East and the West]. The Polish Journal of the Arts and Culture, 3. 55-76. 